\title{
Criminal Victimization: Women and Fintech Financing from the Theory of Lifestyle Exposure
}

\author{
Marisa Kurnianingsih; Aidul Fitriaciada; Khudzaifah Dimyati; Absori; Kelik Wardiono; \\ Kuswardani; Alfan Dzikria Nurrachman \\ Universitas Muhammadiyah Surakarta, Indonesia \\ http://dx.doi.org/10.18415/ijmmu.v9i2.3357
}

\begin{abstract}
Women in the digital era are one of the most vulnerable parties to become victims. Not only as victims of physical violence but also users who have the highest number. There are various reasons why women are currently very active in using various digital platforms or applications on the market, one of which is online loan applications (financial technology). They use the application for various purposes, such as to meet personal basic needs, finance household life, to buy trending goods that are expensive. In the end, because these various goals caused new problems for them, namely debts with high interest accompanied by various threats from irresponsible parties. This article was written using a normative method that aims to review the extent to which the role of women who are victims of the rise of various fintechs, both licensed and illegal in terms of victimology. Here it can be seen that women have a role in the occurrence of financing agreements through Fintech, although the role of women has a passive tendency, but women have a role in the occurrence of fintech financing agreements which ultimately lead to digging holes, closing the hole from the loans they have received. In addition to these problems, women based on the theory of lifestyle exposure are also at risk of becoming victims of immoral crimes in digital media when they are bound by fintech financing agreements in the form of distributing the identity and personal photos of the victims.
\end{abstract}

Keywords: Women; Fintech Financing; Victimization; Crime; Lifestyle

\section{Introduction}

In the digital era, technology has become one of the mandatory tools for humans to be able to support their activities. By being able to access technology, it will facilitate human activities ranging from personal needs to completing work. In the digital era, the form of lending can be easy along with the presence of online loans or what is called Financial Technology(Pristin Prima Sari, 2019). Fintech or financial finance technology is a term that refers to companies that offer offerings using the latest technology in the financial sector. The Fintech concept adapts technological advances in collaboration with the financial sector at banking institutions, so that it is expected to be able to facilitate financial transactions that were originally limited by space and time to become fast, practical, modern. 
There are various forms of Financial Technology in Indonesia, such as Kredivo, Akulaku, Danakita, friends' money, cash we borrow money, our money, and others. The presence of Financial Technology has had a positive impact on society and Fintech has an important role in accessing financial inclusion and financial stability(Pristin Prima Sari, 2019). The presence of Fintech can make it easier and closer to access for business actors, such as MSMEs to reach financial service products and apply for financing without being hampered by space and time(Muzdalifa et al., 2018). With the presence of current financial financing technology, it also has a positive impact on increasing the income of business owners who are starting businesses. Business owners are able to access technology to facilitate the process of business transactions, including obtaining access to credit. In getting access to credit digitally, the financing process becomes efficient(Pristin Prima Sari, 2019).

With the rapid development of technology, the number of Fintech industries is increasingly widespread but has not been matched by strict supervision. On the other hand, with the development of Fintech, the number of people who are interested is increasing, especially women. With the high number of users, the majority of whom are women, this opens up wider opportunities for crimes against women to occur if they as loan recipients are unable to pay the principal and interest on the loan. It can also get worse if predominantly female users are caught up in the Illegal Fintech industry offerings which can at any time disseminate their personal identities and photos to the public accompanied by various threats that can embarrass users.

These various things can cause new problems that are increasingly complicated for women such as severe depression, the occurrence of domestic violence in the household due to insufficient economic problems and can lead to divorce.

The Financial Services Authority once released that there were 1130 complaints of illegal fintech victims in November 2018. The types of violations in the form of high late fines, high interest, and terror from fintech companies aimed at borrowers. Various violations occurred due to the lack of public awareness about the misuse of personal data(Wijayanto et al., 2020). With the lack of public awareness and forms of protection for users, especially women who are dominant, as a result, when service users are trapped by offers from one of the fintechs that are illegal, borrowers enjoy services that can be analogized as poison.(Priyonggojati, 2019).

\section{Research Methods}

In order to answer the problems raised in the previous section, this paper will use a normative juridical approach by means of a critical study of library materials and legal documents that are relevant to the problems of women as victims of the financial technology industry. This writing will use a conceptual approach by analyzing the position of women as victims of the fintech industry that has occurred in Indonesia in order to make it easier to understand the context of the problems that occur, as well as an approach through legislation that is carried out through analysis and evaluation of legislation that has a relationship with problems.

\section{Formulation of the Problem}

To answer the problems that have been stated, the following is a problem formulation that will facilitate data collection and compilation, so that writing can be done in depth and with the right target. The formulation of the problem in this writing is as follows: 
1. How is the regulation of the financial technology industry in Indonesia?

2. What is the role of women as victims of the fintech industry when viewed from the Lifestyle Exposure Theory?

\section{Discussion Result}

\section{A. Regulation of the Financial Technology Industry in Indonesia}

The digital world has brought industrial revolution in various countries. The gradual transformation occurred in production, management, and industrial governance. Disruptive innovation has been present and changes, replaces, or updates with various innovations. The impact on the financial services sector is now present in Fintech. The Financial Technology industry can direct financial services towards a new business model according to Pricewaterhouse Coopers. Fintech utilizes a variety of the latest software, internet, communication and computing technologies. The industry is dubbed Disruptive because it destroys an established industry (Ulya \& Musyarri, 2020).

In the use of information technology and innovation in the financial services sector in Indonesia, various financial services using information technology from the Financial Technology Industry have become familiar to the public, both those offered through financial institutions supervised by the Financial Services Authority and those offered by companies. start-ups (companies that have not been registered with OJK) (Njatrijani, 2019). Currently OJK regulates the growing Fintech Industry in Indonesia, because OJK sees the urgency of the need for provisions to regulate the Fintech Industry by taking into account the many debt cultures that exist in Indonesian society.

The Financial Services Authority as the competent authority on financial services has an obligation to protect consumers of financial services. Consumer protection basically includes various things, such as product obligations, privacy rights, unfair business practices, fraud, misrepresentation, business interactions and others. Law Number 21 of 2011 concerning OJK has stated in Article 4 letter c that OJK aims to protect the interests of the public and consumers. OJK can take actions such as providing information and education, asking financial service institutions to stop their activities, as well as providing consumer complaints services to protect consumers(Science et al., 2021).

To support efforts to regulate various Fintechs in Indonesia, OJK has also issued POJK No. 77/POJK.01/2016 concerning Information Technology-Based Lending and Borrowing Services, which in turn has derivatives in the form of OJK Circular Letter No.18/SEOJK.02/2017 (Njatrijani, 2019).

The Financial Services Authority has also issued POJK No.1/POJK.07/2013 concerning Consumer Protection in the Financial Services Sector, which regulates the principles of consumer protection that must be available to consumers, including fintech consumers as users of financial services. The principles mentioned are a form of transparency, fair treatment, reliability, confidentiality and security of consumer data/information, complaint handling as well as consumer dispute resolution on the simple, fast, and low-cost principle as regulated in Article 2. Then there is Article 31 which contains a prohibition on data consumers for financial services business actors (PUJK).

The prohibition applies so as not to provide data and/or information about consumers to other parties in any way, except with written permission from the consumer and or because it is required by laws and regulations. Furthermore, Article 49 requires FSBs to have and implement written policies as well as procedures regarding consumer protection(Benuf et al., 2019). Then OJK also issued SE OJK No. 
14/SEOJK.07/2014 concerning Confidentiality and Security of Consumer Data and/or Personal Information which contains instructions for implementing the principles of confidentiality and security of consumer data and/or personal information.

Another OJK regulation that regulates the existence of Fintech is POJK No. 13/POJK.02/2018 concerning Digital Financial Innovation in the Financial Services Sector which includes updating business processes, business models, and financial instruments that provide new added value in the financial services sector by presenting digital ecosystem.

In addition to OJK, the regulation of the Financial Technology Industry is regulated by Bank Indonesia in BI Regulation No. 18/17/PBI/2016 concerning Electronic Money (e-money) and Bank Indonesia Regulation No. 19/12/PBI/2017 concerning Fintech Implementation, in which Article 3 paragraph (1) lists several scope categories such as payment systems (digital payments), market support, investment management and risk management, loans, financing and capital provision, and lastly other financial service arrangements (Benuf et al., 2019).

Fintech regulation is also regulated in the Regulation of the Minister of Communication and Information of the Republic of Indonesia Number 4 of 2016 concerning Information Security Management System which contains an information security management system with the determination of terms that can be used in the arrangement. The core material contains categories such as electronic systems, information security management system standards, certification bodies, issuance of certificates, reporting of certification results, and revocation of certificates, self-assessment, guidance, supervision, and applicable sanctions provisions.(Njatrijani, 2019). Then there is Permenkominfo No 5/2016 concerning Trial of Communication, Informatics and Broadcasting Technology which contains a review of research on technical aspects as well as non-technical aspects related to the operation of telecommunications, informatics, and broadcasting.

The next regulation is the Regulation of the Minister of Communication and Information of the Republic of Indonesia Number 20 of 2016 concerning Protection of Personal Data in Electronic Systems whose contents regulate the protection of personal data in electronic systems by setting limits on the terms used in the regulation. Protection of personal data in electronic systems includes protection of the acquisition, collection, processing, analysis, storage, appearance, announcement, delivery, distribution and destruction of personal data as contained in Chapter II of the Ministerial Regulation concerning the protection of personal data. In addition, this regulation regulates the rights of the owner of personal data, user obligations, obligations of electronic system administrators, dispute resolution, the role of government and society, supervision, and administrative sanctions.(Njatrijani, 2019).

Fintech in its journey is regulated in such a way as to comply with the rules issued by authorized regulators such as the Ministry of Communication and Information of the Republic of Indonesia. The implementation of the Fintech business is also regulated in Law No. 19 of 2016 concerning Amendments to Law No. 11 of 2008 concerning Information and Electronic Transactions. Arrangements for the implementation are contained in Article 1 number 17 and Article 18 which contain provisions for electronic contracts, where the contract is an agreement between the two parties which is realized through an electronic system.(Benuf et al., 2019). 


\begin{tabular}{|c|c|c|c|c|}
\hline \multicolumn{5}{|c|}{ Fintech Industry Regulation in Indonesia } \\
\hline No & $\begin{array}{l}\text { Financial } \quad \text { Fervices } \\
\text { Authority }\end{array}$ & Bank Indonesia & $\begin{array}{l}\text { Minister of } \\
\text { Communication } \\
\text { and Information }\end{array}$ & Government \\
\hline 1. & $\begin{array}{l}\text { Law No. } 21 \text { of } 2011 \\
\text { concerning the Financial } \\
\text { Services Authority }\end{array}$ & $\begin{array}{l}\text { BI Regulation No. } \\
\text { 18/17/PBI/2016 } \\
\text { concerning } \\
\text { Electronic Money } \\
\text { (e-money) }\end{array}$ & $\begin{array}{l}\text { Permenkominfo No } \\
4 / 2016 \text { concerning } \\
\text { Information } \\
\text { Security } \\
\text { Management } \\
\text { System }\end{array}$ & $\begin{array}{l}\text { Law No. } 19 \text { of } \\
2016 \text { concerning } \\
\text { Amendments to } \\
\text { Law No. } 11 \text { of } \\
2008 \text { concerning } \\
\text { Information and } \\
\text { Electronic } \\
\text { Transactions }\end{array}$ \\
\hline 2. & $\begin{array}{l}\text { POJK No. } \\
\text { 01/POJK.07/2013 } \\
\text { concerning Consumer } \\
\text { Protection in the } \\
\text { Financial Services Sector }\end{array}$ & $\begin{array}{l}\text { BI Regulation No. } \\
19 / 12 / \mathrm{PBI} / 2017 \\
\text { concerning the } \\
\text { Implementation } \\
\text { of Financial } \\
\text { Technology }\end{array}$ & $\begin{array}{l}\text { Permenkominfo No } \\
5 / 2016 \text { concerning } \\
\text { Trial of } \\
\text { Communication, } \\
\text { Informatics and } \\
\text { Broadcasting } \\
\text { Technology. }\end{array}$ & \\
\hline 3. & $\begin{array}{l}\text { POJK } \\
\text { 13/POJK.02/2018 No } \\
\text { concerning Digital } \\
\text { Financial Innovation in } \\
\text { the Financial Services } \\
\text { Sector }\end{array}$ & & $\begin{array}{l}\text { Permenkominfo No } \\
20 / 2016 \text { concerning } \\
\text { Protection of } \\
\text { Personal Data in } \\
\text { Electronic Systems }\end{array}$ & \\
\hline 4. & $\begin{array}{l}\text { POJK No. } \\
\text { 77/POJK.01/2016 } \\
\text { concerning Information } \\
\text { Technology-Based } \\
\text { Lending and Borrowing } \\
\text { Services }\end{array}$ & & & \\
\hline 5. & $\begin{array}{lr}\text { SEOJK } & \text { No. } \\
\text { 14/SEOJK.07/2014 } \\
\text { concerning } \\
\text { Confidentiality and } \\
\text { Security of Consumer } \\
\begin{array}{l}\text { Data and/or Personal } \\
\text { Information }\end{array} \\
\end{array}$ & & & \\
\hline 6. & $\begin{array}{l}\text { SEOJK No. } \\
\text { 18/SEOJK.02/2017 } \\
\text { concerning Governance } \\
\text { and Risk Management of } \\
\text { Information Technology } \\
\text { in Information } \\
\text { Technology-based } \\
\text { Lending and Borrowing } \\
\text { Services }\end{array}$ & & & \\
\hline
\end{tabular}




\section{B. The Role of Women as Victims of the Fintech Industry as seen from Victimology}

Crime is something that always gives birth to a victim who is someone with a physical condition who suffers and there is an emotional disturbance which shows that the victim's legal rights are deprived. In crime, there are other elements outside the victim, namely the perpetrator and the witness. When a crime occurs, not everything can be seen with the naked eye or clearly about who the real victims, perpetrators, and witnesses are (No Title, 2019).

In general, victims are parties who suffer material or immaterial, spiritual or physical losses due to actions taken by someone for unlawful interests. Victims are not only the cause and basis of the crime process but also play a role in seeking material truth (Person et al., nd).

When there are victims, these problems are part of human rights issues in general. In the development of national law, at first it did not pay attention to the interests of victims, but with the holding of international forums discussing victims of crime such as the Geneva Congress, the Congress in Caracas, and the Congress in Milan, in the end there was attention to the victims of criminal acts. Departing from this, each country is expected to take responsibility for preparing forms of compensation such as making insurance programs for victims (victim, nd).

Based on the thoughts of Indonesian criminal law experts, the determination of a person who suffers a loss is based on the principles of civil law and the loss arises as a result of the actions of an actor based on criminal law is referred to as a "dader". (08 NCO Sura). In Indonesia, the existence of a victim has been regulated in Law Number 13 of 2006 concerning the Protection of Witnesses and Victims, where the interests of victims are authorized by an institution known as the Witness and Victim Protection Agency (LPSK) (victim, nd).

Victims of crime in the past tended to be ignored for their existence and their rights were not considered. However, at this time there is a growing concern for victims of crime, thus encouraging the emergence of victimology as a scientific study of victims. There are six factors that support the presence of victimology based on the thoughts of Dignan (2005) which has been quoted by Newburn (2007), namely as follows:(Mustofa, 2005).

- The interests of the victims must be considered according to the thinking of Margery Fry (the punitive reform thinker of the 1940s).

- Mass media that publicizes the suffering of victims of crime.

- Increased recognition of the presence of vulnerable groups in the 1960s.

- The emergence of interesting cases in the international or domestic sphere that publicizes the victim.

- Increased knowledge regarding crime victims through surveys.

- The criminologist's confession regarding the urgency of understanding the victim of a crime and then resulting in the discipline of victimology

In the digital era that is present so rapidly, there are now various crimes that are more vulnerable to befall the community, especially a woman, for example, invasion of privacy, threats to distribute personal photos or videos, defamation and others. The increasing number of crimes against women as victims, should be a lesson for the community that it would be better for all parties, especially wise women when they would use internet technology in carrying out their daily activities and routines, even in a state of urgency.(Era et al., nd).

According to Mustofa, there was a major criminal victimization theory that was produced in the field of victimization around 1978 when Hindelang Gottfredson and Garofalo formulated a theory of 
victimization due to lifestyle exposure. Lifestyle Exposure Theory aims to measure the differences in each social group in the risk of facing crime victimization in the form of physical or psychological violence as well as the risk of victimization of crimes against property. The basic assumption of the Lifestyle Exposure Theory is to describe the differences in the risk of people in facing crime victimization influenced by the presence of differences in the lifestyle of each individual.(Era et al., nd).

From the theory of lifestyle exposure there are several possibilities related to this theory. First, in the community element, there are sections that are vulnerable to being victims of crime (certain groups who have a high risk) and secondly, there is a possibility that behavioral characteristics have similarities with the characteristics of victims. According to Simon Singer's research, it was found that if there are victims who have experienced violence before, they are likely to become perpetrators of violence as well.

Based on the theory of lifestyle exposure related to the current era conditions that are rampant with the presence of the Digital Financial Services Sector Industry (Financial Technology), it can be understood that women are at risk of becoming a high-risk group, because this group has a variety of heterogeneous lifestyles. In today's digital era, women are also a group that tends to be narcissistic, this is based on the behavior patterns of women who are more dominant in digital activities such as making and posting photos, videos, and personal identities easily without vigilance.

With this pattern of behavior, it is very risky to be used by irresponsible parties to terrorize the parties concerned if there are women who join as Fintech customers and do not have the ability to repay the loans they have received.

From the above, if terror continues, it can cause pressure on the mental or psychological state of women who are customers of Fintech. This can cause an even more severe impact, if the pressure occurs when the situation is accompanied by a personal conflict from a woman herself, for example, domestic violence occurs due to insufficient economic factors, causing the settlement of domestic relations to be forced through divorce.

On the other hand, the phenomenon of the rise of fintech, apart from being influenced by the large number of potential customers with their various lifestyles, the increasing number of fintechs is also influenced by the number of individuals in the fintech structure who may also want more material in a short time. This can then be potentially used by fintech structural parties to justify various methods, including sending threats or various terrors to fintech customers to pay off their loans immediately, so that the fintech structural parties themselves can immediately get the material back in large amounts.

\section{Conclusion}

1.Indonesia already has regulations to regulate the growth and development of Fintech, both issued by the Financial Services Authority, Bank Indonesia, and the Ministry of Communication and Information of the Republic of Indonesia. Existing regulations already regulate various matters, such as user and operator obligations, user and operator rights, dispute resolution, government and community roles, industrial supervision, administrative sanctions and others.

2. Based on the theory of lifestyle exposure, women are a vulnerable group who have the potential to become victims of Fintech Financing due to personal factors such as a high tendency to distribute photos, videos, and personal identities without being aware of various irresponsible people. In addition, there are other factors such as the increasing lifestyle of the community itself, especially female 
consumers and elements of Fintech organizers, causing various negative impacts for the parties concerned.

\section{Suggestion}

1.Indonesia already has various regulations, but the implications and synergies between the supervisory institutions for implementing Fintech still tend to be minimal, when compared to the very rapid development of Fintech. The supervisory agency for Fintech providers should need to increase the synergy between institutions with each other, so that supervision of Fintech is more optimal and on target.

2.The public, especially women, must be more careful in carrying out digital activities that have the potential to spread their own privacy, so as to minimize the possibility of misuse of personal privacy by irresponsible persons. In addition, the community should be able to better control the various needs of their lives, thereby reducing dependence on loans or debt.

\section{References}

\section{Journal}

Abdullah Rahmat Hi. 2019. Tinjauan Viktimologis terhadap Tindak Pidana Perdagangan Orang (Human Trafficking). Jurnal Yustika, XXII, (01), 56.

Benuf, Kornelius dkk. 2019. Perlindungan Hukum terhadap Keamanan Data Konsumen FinancialTechnology di Indonesia. Refleksi Hukum Jurnal Ilmu Hukum, III, (02), 146.

Mustofa, Muhammad. 2005. Viktimologi Posmodern. Jurnal Kriminologi Indonesia, XXIII, (02), 58.

Muzdalifa, Irma dkk. 2018. Peran Fintech dalam Meningkatkan Keuangan Inklusif pada UMKM di Indonesia. Jurnal Masharif al-Syariah: Ekonomi Perbankan Syariah, III, (01).

Njatrijani, Rinitami. 2019. Perkembangan Regulasi dan Pengawasan Financial Technology di Indonesia. Diponegoro Private Law Review, IV, (01), 463.

Priambada, Bintara Sura. 2014. Pengaruh Financial Technology terhadap Kepuasan Keuangan dengan Capaian Keuangan sebagai Variabel Mediasi. Jurnal Unsa, III, (02), 3.

Priyonggojati, Agus. 2019. Viktimologi dalam Sistem Peradilan Pidana tentang Kepentingan Korban. Jurnal USM Law Review, II, (02), 162.

Ramailis, Neri Widya. 2020. Cyber Crime dan Potensi munculnya Viktimisasi Perempuan di Era Teknologi Industri 4.0. Jurnal UIR, V, (01), 2.

Sari, Pristin Prima dkk. 2019. Pengaruh Financial Technology terhadap Kepuasan Keuangan dengan Capaian Keuangan sebagai Variabel Mediasi. Kajian Bisnis, XXVII, (02), 135.

Ulya, Nurul dkk. 2020. Reformulasi Pengaturan mengenai Financial Technology dalam Hukum Positif di Indonesia. Arena Hukum, XIII, (03), 480. 
Wijayanto, Hendro dkk. 2020. Analisis Penyalahgunaan Data Pribadi dalam Aplikasi Fintech Ilegal dengan Metode Hibrid. Jurnal Ilmiah Sinus, XVIII (01), 02.

Furqanita, Jihan Ayuzein dkk. 2021. Pertanggungjawaban Penyelenggara Fintech Peer to Peer Landing. Jurnal Kenotariatan Fakultas Hukum Universitas Padjajaran, IV, 280.

\section{Internet}

Puspa, I Wayan, Teori-Teori Viktimisasi Kriminal, https://www.scribd.com/doc/208701655/Teori-Teori Viktimisasi-Kriminal. diakses pada tanggal 15 November 2021 Pukul 01.30 WIB

\section{Copyrights}

Copyright for this article is retained by the author(s), with first publication rights granted to the journal.

This is an open-access article distributed under the terms and conditions of the Creative Commons Attribution license (http://creativecommons.org/licenses/by/4.0/). 